\title{
UPAYA MENINGKATKAN HASIL BELAJAR EKONOMI DENGAN MENGGUNAKAN MODEL PEMBELAJARAN KOOPERATIF TIPE TWO STRAY TWO STRAY (TSTS)
}

\author{
Oleh : Dr. Iin Nurbudiyani, M.Pd* dan Yean’s Virgi Handhayanie**
}

\begin{abstract}
ABSTRAK
Penelitian ini bertujuan untuk mengetahui : (1) aktivitas belajar peserta didik dalam pembelajaran ekonomi dengan menggunakan model pembelajaran kooperatif tipe Two Stay Two Stray, (2) mengetahui peningkatan hasil belajar ekonomi peserta didik setelah menggunakan model pembelajaran kooperatif tipe Two Stay Two Stray. Subjek dalam penelitian ini adalah kelas X IPS Madrasah Aliyah Miftahul Jannah Palangka Raya sebanyak 20 orang peserta didik. Metode yang digunakan peneliti adalah menggunakan rancangan Penelitian Tindakan Kelas (PTK). Berdasarkan hasil penelitian disimpulkan bahwa: (1) aktivitas belajar peserta didik kelas X IPS Madrasah Aliyah Miftahul Jannah Palangka Raya lebih aktif pada saat pembelajaran ekonomi menggunakan model pembelajaran kooperatif tipe Two Stay Two Stray. (2) Hasil belajar peserta didik mengalami peningkatan, pada siklus I ketuntasan secara klasikal mencapai 55\% (11 orang) peserta didik tuntas. Pada siklus II persentase hasil belajar meningkat yaitu ketuntasan secara klasikal mencapai 95\% (19 orang) peserta didik yang tuntas.
\end{abstract}

\section{Kata Kunci : Hasil Belajar Ekonomi, Model Pembelajaran Kooperatif Two Stay} Two Stray

\section{PENDAHULUAN}

Untuk mencapai tujuan pendidikan, tidak hanya menjadi tugas guru saja, melainkan menjadi peran orang tua, masyarakat, dan peserta didik itu sendiri, karena pendidikan erat kaitannya dengan belajar, sebab belajar merupakan tindakan perilaku peserta didik yang kompleks.

Peserta didik adalah penentu terjadinya atau tidak terjadinya suatu proses belajar. Peserta didik belajar tidak hanya di sekolah, melainkan dikeluarga dan masyarakat, itu sebabnya orang tua dalam ruang lingkup keluarga serta masyarakat dapat menjadi penentu berhasilnya proses belajar mengajar bagi peserta didik. Dalam proses kegiatan belajar mengajar, banyak sekali masalah yang dihadapi oleh seorang guru, terutama dalam menghadapi peserta didik yang kurang memperhatikan pelajaran dan masalah yang ada pada diri peserta didik sehingga dapat menghambat keberhasilan belajar. Menurut Daryanto (2010:2) "Belajar adalah suatu proses usaha yang dilakukan seseorang untuk memperoleh suatu perubahan tingkah laku yang baru secara keseluruhan, sebagai hasil pengalamannya sendiri dalam interaksi dengan lingkungannya”. 
Untuk melihat keberhasilan suatu kegiatan pembelajaran, ranah yang dinilai atau ingin diketahui guru tidak hanya pada ranah kognitifnya saja yang berhubungan dengan ingatan atau pengenalan terhadap pengetahuan dan informasi, serta pengembangan keterampilan intelektual, melainkan ranah afektif yang berhubungan dengan hierarki perhatian, sikap, nilai, penghargaan, dan emosi, serta ranah psikomotorik yang berhubungan dengan keterampilan motorik, manipulasi benda atau kegiatan yang memerlukan koordinasi syaraf. Guru dapat mengetahui dengan jelas ketiga ranah tersebut baik sebelum maupun sesudah melakukan evaluasi belajar.

Menurut Oemar Hamalik (2006:30) mengemukakan bahwa "Hasil belajar adalah bila seseorang telah belajar akan terjadi perubahan tingkah laku pada orang tersebut,misalnya dari tidak tahu menjadi tahu, dari tidak mengerti menjadi mengerti”.

Untuk meningkatkan minat belajar pada peserta didik yang utama justru menjadi tanggung jawab semua pihak, termasuk guru. Guru mempunyai peran yang sangat penting terhadap peningkatan minat belajar peserta didik selama berada dalam pendidikan formal.

Dengan meningkatkan minat belajar peserta didik maka diharapkan dapat membangkitkan keinginan belajar peserta didik sehingga dapat belajar lebih aktif. Menurut Sudirman (2007:39) "Faktor-faktor yang mempengaruhi hasil belajar adalah faktor intern (dari dalam) diri siswa dan faktor ekstern (dari luar) siswa".
Dalam proses pembelajaran antara pendidik dan peserta didik harus ada interaksi. Pendidikan pada dasarnya merupakan interaksi antara pendidik dengan peserta didik, untuk mencapai tujuan pendidikan, yang berlangsung dalam lingkungan tertentu. Interaksi belajar mengajar adalah kegiatan timbal balik antara guru dengan peserta didik, dengan adanya suatu interaksi yang baik antara guru dan peserta didik maka akan membuat proses pembelajaran menjadi lebih baik dan membuat peserta didik lebih aktif.

Berdasarkan pengamatan yang dilakukan oleh peneliti pada peserta didik kelas X IPS di Madrasah Aliyah Miftahul Jannah Palangka Raya yang menunjukkan bahwa pada saat pembelajaran ekonomi, kegiatan yang terjadi adalah komunikasi satu arah, yang aktif masih didominasi oleh pengajar. Hal ini terlihat jarangnya peserta didik yang bertanya kepada guru. Peserta didik lebih banyak diam, dan mendengarkan apa yang disampaikan oleh guru.

Menurut Ruslikan (2011:33), "Ilmu ekonomi adalah ilmu yang mempelajari tentang kemampuan masyarakat dalam mengelola SDA (Sumber Daya Alam) untuk memenuhi kebutuhan hidupnya".

Banyak peserta didik yang kurang bersemangat dalam mengikuti pelajaran ekonomi. Saat kegiatan belajar mengajar (KBM) berlangsung tidak sedikit juga siswa yang ribut dan mengganggu sesama teman di dalam kelas. Setiap diberikan pekerjaan rumah (PR), peserta didik kerap sekali tidak mengumpulkan tugas dengan tepat 
waktu, dan saat diberikan tugas masih banyak peserta didik yang mendapatkan nilai di bawah Kriteria Ketuntasan Minimal (KKM), nilai KKM yang ditentukan oleh pihak sekolah adalah 75 , dari 20 peserta didik hanya 8 orang yang mencapai kriteria ketuntasan minimal (KKM) dan nilai ini didapat dari guru mata pelajaran ekonomi yaitu Ibu Tri Hutani pada Madrasah Aliyah Miftahul Jannah Palangka Raya.

Untuk mengatasi hal tersebut dibutuhkan suatu strategi dan metode yang tepat. Maka dari itu peneliti berusaha untuk memilih strategi dan model pembelajaran yang tepat sesuai dengan kondisi yang ada di sekolah, yaitu model pembelajaran kooperatif tipe Two Stay Two Stray.

$$
\text { Miftahul Huda (2013:207) }
$$

mengemukakan bahwa: Dua tinggal dua tamu (Two Stay Two Stray) merupakan sistem pembelajaran kelompok dengan tujuan agar siswa dapat saling bekerja sama, bertanggung jawab, saling membantu memecahkan masalah, dan saling mendorong satu sama lain untuk berprestasi. Sedangkan menurut Warsono dan Hariyanto (2012:235) mengemukakan bahwa "Dua tinggal dua tamu (Two Stay Two Stray) merupakan sistem pembelajaran yang mendorong siswa untuk berfikir kreatif dan analitis dalam kelompok".

Dengan penggunaan model pembelajaran kooperatif Two Stay Two Stray (TSTS) ini, diharapkan pembelajaran menjadi lebih menarik dan menyenangkan, akan mengarahkan siswa untuk aktif, dapat meningkatkan motivasi belajar peserta didik serta meningkatkan aktivitas dan tanggung jawab peserta didik dalam proses pembelajaran. Berdasarkan permasalahan yang terjadi peneliti tertarik untuk mengangkat judul penelitian "Upaya Meningkatkan Hasil Belajar Ekonomi Dengan Menggunakan Model Pembelajaran Kooperatif Tipe Two Stray Two Stray (TSTS)". Tujuan penelitian ini untuk mengetahui aktivitas belajar peserta didik dengan menggunakan model pembelajaran kooperatif tipe Two Stay Two Stray (TSTS) dan untuk mengetahui peningkatan hasil belajar ekonomi peserta dengan menggunakan model pembelajaran kooperatif tipe Two Stay Two Stray (TSTS).

\section{METODE PENELITIAN}

Dalam pelaksanaan peneliti menggunakan model Penelitian Tindakan Kelas (PTK). Penelitian tindakan kelas juga merupakan penelitian yang bersifat reparatif. Artinya, penelitian yang dilakukan untuk memperbaiki proses pembelajaran agar peserta didik dapat mencapai hasil maksimal.

Dalam penelitian ini hal utama yang harus diperhatikan adalah sikap, karena dengan sikap yang baik dimiliki peneliti maka akan menciptakan sesuatu hal yang disenangi oleh para subjek atau para pemberi informasi. Bukan hanya sikap tetapi juga dengan pakaian rapi, interaksi yang baik, dan lain-lain demi terciptanya hubungan baik dan rasa persahabatan dengan para semua pihak sekolah.

Dari pendekatan yang dilakukan peneliti saat observasi di Madrasah Aliyah Miftahul Jannah Palangka Raya, maka terciptalah hubungan baik terhadap subjek penelitian. Sehingga 
akan memudahkan langkah pada penelitian selanjutnya, untuk mencari keterangan yang diperlukan dalam menyusun penelitian. Peneliti adalah pihak yang merasakan adanya masalah yang perlu diselesaikan. Peran peneliti dalam penelitian ini adalah sebagai pengampu kelas atau pelajaran yang menjadi tempat penelitian.

Subjek penelitian yaitu, peserta didik kelas X IPS Madrasah Aliyah Miftahul Jannah Palangka Raya tahun pelajaran 2014/2015. Dengan jumlah peserta keseluruhan peserta didik sebanyak 20 peserta didik. Penelitian ini menggunakan rancangan PTK yang dicirikan dengan adanya siklus-siklus, setiap siklus terdiri dari empat tahapan yaitu: Pereancanaan, pelaksanaan tindakan, observasi, dan refleksi/evaluasi.

Teknik pengumpulan data yang digunakan dalam penelitian ini adalah berupa dan observasi tes hasil belajar. Instrument dalam penelitian ini adalah dengan instrument tes hasil belajar. Instrument tes hasil belajar yang digunakan pada penelitian ini adalah pre-test (tes awal) dan post-test (tes akhir).

Data yang dikumpulkan dari setiap kegiatan yang dilakspeserta didikan dalam siklus PTK dianalisis secara deskriftif dengan menggunakan teknik persentase untuk melihat kecenderungan yang terjadi dalam pembelajaran. Data yang diperoleh melalui instrument yang telah dikumpulkan sebelumnya diolah menjadi dua jenis data yaitu kuantitatif dan kualitatif.
Indikator keberhasilan yang ingin dicapai dalam penelitian ini sebagai berikut:

1. Aktivitas belajar peserta didik dianggap berhasil atau baik jika setiap peserta didik memperoleh skor di atas 45 kriteria individual, dengan kriteria baik.

2. Hasil belajar peserta didik dianggap tuntas jika memperoleh skor lebih besar dari nilai KKM yaitu 75, sedangkan secara klasikal hasil belajar peserta didik minimal $85 \%$ peserta didik memperoleh skor di atas nilai KKM yaitu 75 .

\section{HASIL DAN PEMBAHASAN}

Dengan menggunakan model pembelajaran tipe Two Stay Two Stray (TSTS), aktivitas peserta didik pada saat proses pembelajaran ekonomi menjadi lebih baik. Hal tersebut dapat dilihat dari lembar observasi yang telah dicatat oleh pengamat/observer pada siklus I dan siklus II yang menunjukan adanya peningkatan.

Pada proses pembelajaran ekonomi yang dilakspeserta didikan oleh peneliti di kelas X IPS MA. Miftahul Jannah Palangka Raya Tahun Pelajaran 2014/2015 pada aktivitas peserta didik menunjukkan kemajuan dan perkembangan dalam mengikuti kegiatan belajar mengajar. Aktivitas belajar peserta didik pada siklus I dan siklus II mencapai kriteria baik.

Adanya peningkatan nilai hasil belajar peserta didik kelas X IPS MA. Miftahul Jannah Palangka Raya Tahun Pelajaran 2014/2015 yang menerapkan model pembelajaran Two Stay Two Stray (TSTS) pada proses pembelajaran 
ekonomi dengan materi Sistem Pembayaran dan Alat Pembayaran terlihat pada tabel beriku:

Tabel 1 Peningkatan Hasil Belajar Peserta Didik siklus Tes awal, Siklus I dan Siklus II

\begin{tabular}{|c|c|}
\hline Siklus & Post-tes \\
\hline Tes Awal & $\mathbf{1 0}$ \\
\hline Siklus I & 55 \\
\hline Siklus II & $\mathbf{9 5}$ \\
\hline
\end{tabular}

Terjadi peningkatan hasil belajar peserta didik ini dibuktikan dari hasil pre test sebesar $10 \%$ atau 2 orang peserta didik yang mecapai di atas KKM, siklus I sebesar $55 \%$ atau 11 orang peserta didik yang mencapai nilai di atas KKM, dan siklus II sebesar 95\% atau 19 orang peserta didik yang mencapai di atas KKM.

\section{KESIMPULAN}

Berdasarkan hasil penelitian yang telah dilakukan, maka dapat diambil kesimpulan bahwa:

1. Aktivias belajar peserta didik pada saat pembelajaran Ekonomi dengan menggunakan model pembelajaran Two Stay Two Stray (TSTS) menjadi lebih aktif. Aktivitas pada siklus I dan siklus II mencapai kriteria baik.

2. Ada peningkatan hasil belajar Ekonomi setelah diajarkan dengan menggunakan model pembelajaran Two Stay Two Stray (TSTS). Hal ini terlihat dari persentase hasil belajar peserta didik pada siklus I ketuntasan secara klasikal mencapai 55\% (11 orang) peserta didik tuntas. Pada siklus II persentase hasil belajar meningkat yaitu ketuntasan secara klasikal mencapai 95\% (19 orang) peserta didik yang tuntas.

\section{DAFTAR PUSTAKA}

Daryanto. (2010). Media Pembelajaran, Peranannya Sangat Penting Dalam Mencapai Tujuan Pembelajaran. Yogyakarta: Gava Media.

Miftahul Huda. (2013). Model-Model Pengajaran Dan Pembelajaran. Yogyakarta: Pustaka Belajar.

Oemar Hamalik. (2006). Proses Belajar Mengajar. Bandung: Bumi Aksara.

Ruslikan. (2011). Pengembangan dan Pembelajaran IPS. Palangka Raya: Midada Rahmah Press.

Sudirman. (2007). Interaksi dan Motivasi Belajar Mengajar. Jakarta: PT. Raja Grafindo Persada.

Warsono dan Hariyanto. (2012). Pembelajaran Aktif. Bandung. PT. Remaja Rosdakarya. 